\title{
The Component of Variation Skill Applied by a Teacher in “Freedom Writers" Film
}

\author{
Norliani \\ STKIP PGRI Banjarmasin \\ norliani@stkipbjm.ac.id
}

\begin{abstract}
The teacher as an educator is one of the essential factors to support the success of education in the class, so a teacher must have teaching skills. This research was conducted to find and describe the component of variation skill applied by a teacher in "Freedom Writers "Film. This research used a descriptive qualitative approach. The data was taken from the movie. The component of variation skill theory used was Turney's theory (1983). The result of data analysis reveals that the teacher in the movie applied all the variation skills component; they were variation in teacher's manner. There are six in these variations: voice variation, focusing, pausing, eye contact, gesturing and movement, variation in media and material instruction, such as visual, aural and tactile, and interaction variation.
\end{abstract}

Keywords: Variations skill, Freedom Writer

\section{BACKGROUND}

The teacher as an educator is one of the essential factors to support the success of educational goals because the teacher is someone who knows the situation in the classroom, someone who knows his students well. He knows what they need .so, the teacher is human resources who can be a planner, actor, and determiner to achieve education goals.

A teacher must have teaching skill in order to sustain the attention of his students. The teacher must master the role in the classroom. For example, he knows the subject matter, learning method, and instructional media. In addition, in achieving the aim of 
the teaching and learning process, the teacher's role is very important because the teacher as a manager who holds the class will run well.

To be a good manager, the teacher has to create and maintain the classroom atmosphere and possible, especially in the teaching and learning process. Class management is one of the fundamental skills of teaching. In this case, the teacher must have the ability to control and inspire a class. One of the basic teaching skills which important in the teaching and learning process is variation skill. When the teacher applied this skill, it is intended to solve the student's boredom. The students will have more attention and understanding in the teaching and learning process, so the effectiveness of the learning process depending on how the teacher manage the class. The teaching and learning process would be good if the teacher can build an enjoyable situation through giving variation skill to students.

The case raised in the film Freedom Writers" is taking stories from a Vocational secondary school in Long Beach, specifically the experience of one classroom of 203 with an English teacher and a new female guardian named Erin Gruwell. She is very intelligent and creative in educating her students.

The film Freedom Writers is told how Mrs Gruwell struggles with many race and conflict problems to be accepted by the students. Mrs Gruwell, with great patience, sincerity, intelligence and high dedication as an educator, strives with all her ability to solve racial and gang conflict within the classroom, with the ultimate goal of ordering class, may return to be normal as a class generally. In this film, the teacher or Mrs Gruwell taught her students, and she used some variation applied in the class during a learning activity.

Based on the background above, the researcher interested to search the teachers' activities in applied the component of variation skill in the teaching and learning process.

\section{PROBLEM FORMULATION}

Based on the background above, the problem formulation in this research is: 
What are the components of variation skill applied by the teacher in the "Freedom Writer" Film.?

\section{RESEARCH OBJECTIVe}

The objective of the research is to describe the components of variation skill applied by the teacher in "Freedom Writers" Film

\section{SIGNIFICANCE}

the result of the research is expected to have a significant contribution in education to develop learning media with more variation, more interesting by using film as a strategy in teaching and learning process, and it will give supporting theory for the teacher in developing their variation skill in teaching and learning process.

\section{PREVIOUS RESEARCH}

There is some related research that has been done previously, the first was conducted by Sani (2012), the title of his research was "component of Variation Skill in Teaching English used by class E of English Education of STKIP PGRI Banjarmasin". He found that the teacher applied variation in teaching, variation in media and subject matters and the teacher also used variation interaction in the classroom.

The second research by Rusnawati (2012), the title of her research was "Component of Variation Skill in Teaching English Used by Seventh Grade English Teacher of SMP Negeri 1 Tamban. She found variations in teaching style, such as teacher's voice, focusing, pausing, eye contact, gesture and teacher movement. The teacher also used variation in media and interaction. There are some differences between this research and the research above. The first is the object of the research. This research uses a film as the object, while the previous research used a teacher as the object. The second is the instrument of the research, the research above used observation as the instrument to collect the data. In contrast, the instrument in this research is the researcher herself, and 
the last is the location, the location of the previous research was at SMP Negeri 1 Tamban and at STKIP PGRI Banjarmasin the location of the film was California.

\section{BASIC TEACHING SKILLS}

Basic skills in teaching is required by the teacher. This research used theory by Asril (2013), he states" keterampilan Dasar mengajar adalah keterampilan standar yang harus dimiliki setiap individu yang berfrpfesi sebagai guru".

He said there are seven points of basic teaching skills:

1. Opening and close the lesson

2. Classroom management

3. Reinforcement

4. Guiding small group

5. Questioning

6. Explaining

7. Variation stimulus

During the teaching and learning process, students will have different feelings such as happy, sad, tired, bored, had no interest in the subject, etc., so one of the main tasks for teachers is to provoke interest and seek strategies to overcome the situations, the teacher can create a learning process by using one of the basic teaching skills one of them is variation stimulus.

\section{COMPONENT OF VARIATION}

According to Turney et al. (1983), there are three components of variation skill:

1. Variation in the teacher's manner or style

a. There are six components in a teacher's manner or style:

b. Voice variation will include changes in the tone, pitch, volume and speed of speech. 
c. Focusing to focus attention is a significant or key aspect. The teacher may use verbal markers of importance, such as watch closely.

d. Pausing, the insertion of spaces of silence in teacher talk and teaching activity is another attention-demanding device. In questioning sequences, the teacher's use of pauses or 'wait-time' after asking a question allows the students to organize the answer.

e. Eye contact, when talking or interacting with the student, the teacher should gaze around the classroom, meeting the student's ayes.

f. Gesturing, refer to expression. Hand, head and body movement are an important aspect of communication.

g. Movement, the movement of the teacher in the teaching space, can help sustain attention and personalize teaching.

2. Variations in media and material instruction

a. Visual, the teacher may use pictures such as drawings, sketches, photographs, paintings, posters, murals, the diagram in the teaching process.

b. Aural variations, in most classroom, the teacher's voice is the main mode of communication, but the teacher can use songs, poems, stories read aloud, film and field trips.

c. Tactile, in this variation, the teacher uses media and materials in the real-life object that the student can touch as well as toys and puppets.

3. Interaction Variation

a. Teacher-pupil interchange variations, the teacher may provide opportunities for the students, possibly working in small groups, to exchange ideas through exposition, discussion or demonstration without his or her intervention. 
b. Pupil activity variations: the learning activities in which pupils may be engaged can also range widely; besides listening to the teacher or participating in class discussion, pupils may contribute in small groups to work individually or in small groups on project or task.

\section{SYNOPSIS OF THE FILM “FREEDOM WRITERS”}

Freedom Writers is a 2007 drama film written and directed by Richard LaGravenese and starring Hillary Swank, Scoot Glenn, Imelda Staunton, and Patrick Dempsey. It is based on the book The Freedom Writers Diary by teacher Erin Gruwell who wrote the story based on Woodrow Wilson Classical High School in Long Beach, California.

Woodrow Wilson Classical High School is a formerly high-achieving school with some difficulties bearing its new racial integration plan. In 1994, Erin Gruwell, an enthusiastic young teacher, starts at the school. Her enthusiasm is challenged when she finds her class is composed of "at-risk" students, the "untouchable", and not the eager college students she expected. These kinds of students became a challenge for her as their teacher. The school judges these students too stupid to read the new book. However, Gruwell said that her students had given up education because of their background. She tried to change her student's assumption about education. She gives the student motivation book and encourages the students to be better person. In this case, she makes efforts to improve the quality of education.

\section{METHOD OF RESEARCH}

\subsection{Design}

This research was a descriptive qualitative research, which aims at describing the the components of variation skill applied by the teacher in "Freedom Writer" film. 


\subsection{Source of Data}

The source of data in this research is obtained from the film "Freedom Writers" to describe the component of variation skill applied by the teacher that found in the film since this film has much good value about how are the roles of educator in the teaching and learning process to create a good atmosphere to students actively and passionately.

\subsection{Instruments}

The instrument of this research is the researcher herself. In collecting the data, the researcher used an analysis document. The data sources documented in this study is in the form of the content in the Freedom Writers film. Techniques of data analysis in this study were gradual. The steps are: watching the film repeatedly, noting the component variation skill that found in the film, categorizing the data into types of variation skill by using Turney 's theory (1983)

\section{RESULT AND DISCUSSION}

Based on the research that has been done, the teacher did three of the various skill. They vary in the teacher's manner style, variation in media and materials instructions, and interaction variation.

Table 4.1. Component of Variation Skills

\begin{tabular}{|l|l|l|}
\hline No & Component of Variation skills & $\begin{array}{l}\text { The scene that shows } \\
\text { the teaching and } \\
\text { learning process in the } \\
\text { film "Freedom Writers." }\end{array}$ \\
\hline 1. & $\begin{array}{l}\text { Variation in the teacher's manner } \\
\text { Voice variations }\end{array}$ & $\mathrm{V}$ \\
& Focusing & $\mathrm{V}$ \\
& Pausing & $\mathrm{V}$ \\
& Eyes contact & $\mathrm{V}$ \\
& Gesturing & $\mathrm{V}$ \\
& movements & $\mathrm{V}$ \\
\hline
\end{tabular}




\begin{tabular}{|l|l|l|}
\hline 2. & Variations in media and materials & \\
& Visual variations & $\mathrm{V}$ \\
& Aural variations & $\mathrm{V}$ \\
& Tactile variations & $\mathrm{V}$ \\
\hline 3. & Interaction variations & \\
& Teacher-pupil interchange variation & $\mathrm{V}$ \\
& Pupil activity variations & $\mathrm{V}$ \\
& & \\
\hline
\end{tabular}

The table above shows that the teacher or Mrs Gruwell applied all the components of variation skill in the teaching and learning process. from all the scene in the film that shows the teaching and learning process and when Mrs Gruwell firstly comes to the class until she taught for years to apply these components.

\section{DISCUSSION}

This part shows a brief explanation of the component of various skills applied by the teacher.

1. Variations in the teacher's manner

a. Voice variation.

Picture 4.1 First meeting in the class
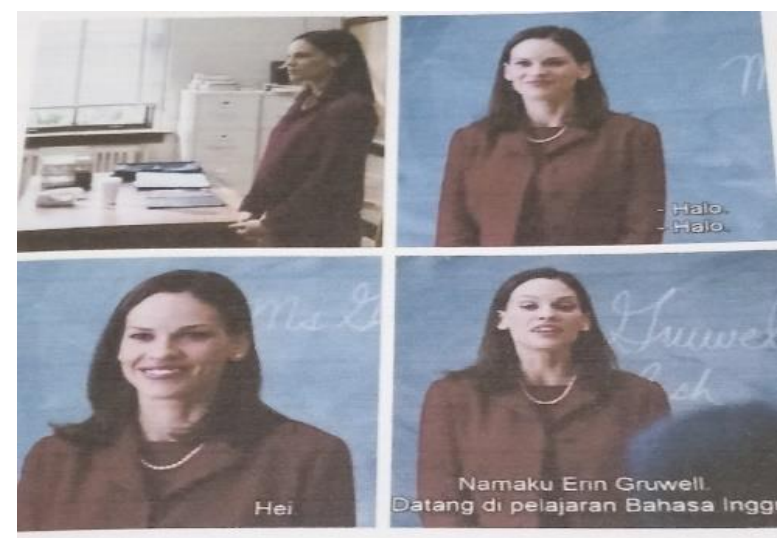
In this scene, Mrs Gruwell introduces herself and explains much about the material, but the students keep silent and treat her badly. Mrs Gruwell smiles, and her voice sometimes loud, sometimes low. Mrs Gruwell speaks louder when a student named Eva ignored Mrs Gruwell when ask her to study. Mrs Gruwell does voice variation to make her speech more clearly heard by all the students.

b. Focusing and Pausing

Picture. 4.2. Mrs Gruwell applied Focusing and Pausing in her class

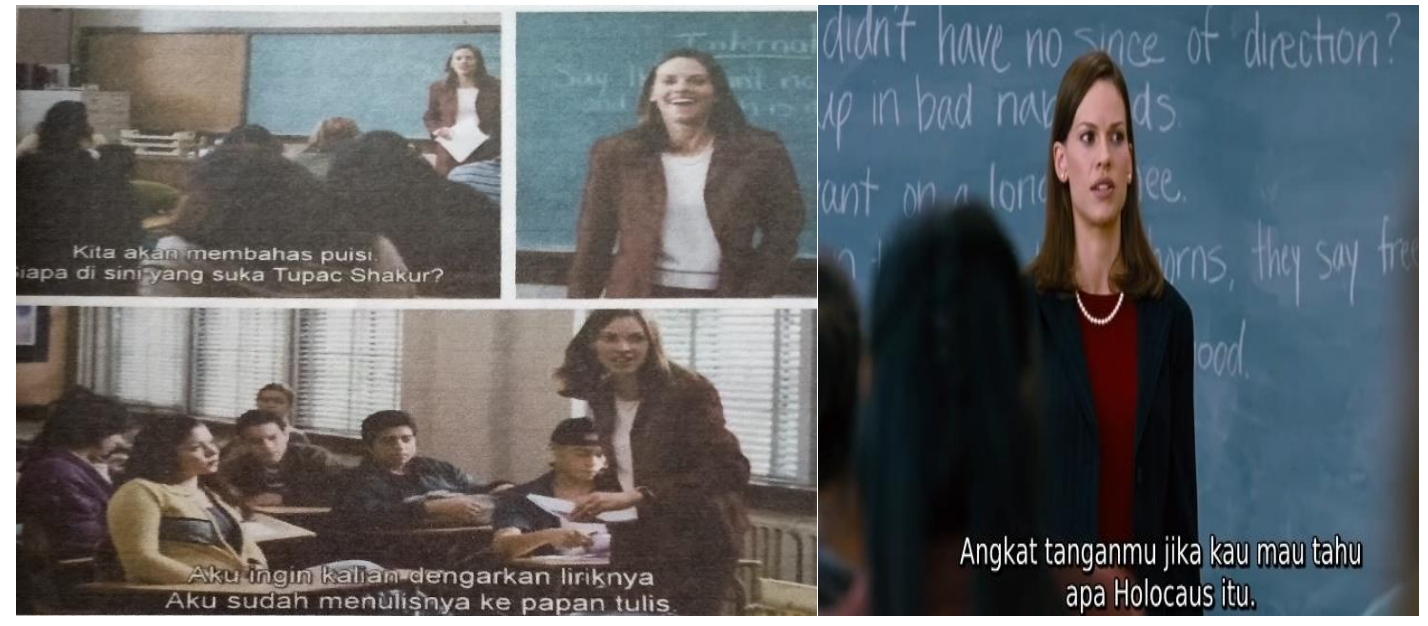

When Mrs Gruwell explained poetry, she applied to focus and pausing at the same time. She invites the students to discuss poetry, and she applied to pause when she asked about Holocaust and Tupac Shakur. Mrs Gruwell gives time for students to organize the answer.

c. Gesturing and Movement variations 
Picture 4.3. Mrs Gruwell applied gesturing and movement variation
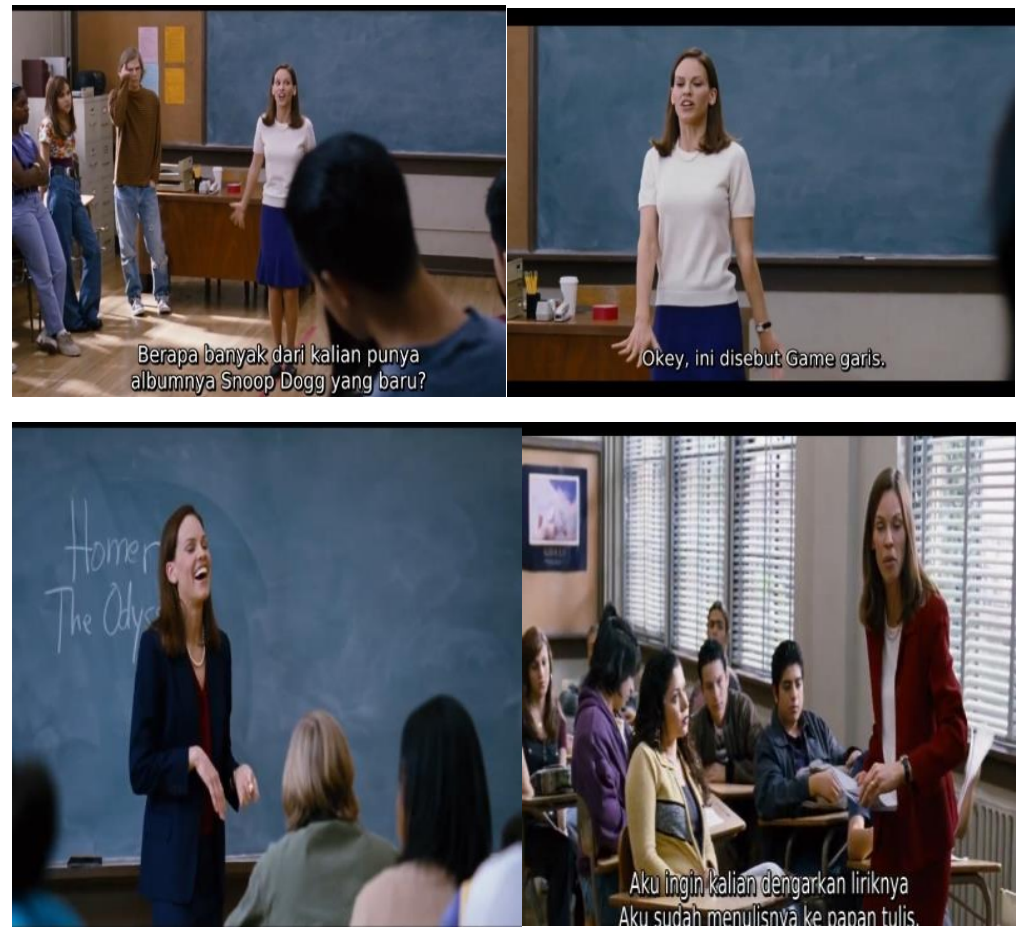

Mrs Gruwell is an active and energetic teacher, so when she taught, she always moves backward, left or right side of the class to make sure all her student listen and understand the material. She always smiles at all students and also behaves humble and generous.

d. Eyes Contact Variation

From all the picture above, we can see clearly that Mrs Gruwell always does eyes contact variation. In order to manage her class successfully, she must be aware of what her students are doing and how they are feeling.

2. Variation in Media and Material Instruction.

Picture. 4.4. Media and Material Instruction that applied by Mrs Gruwell 

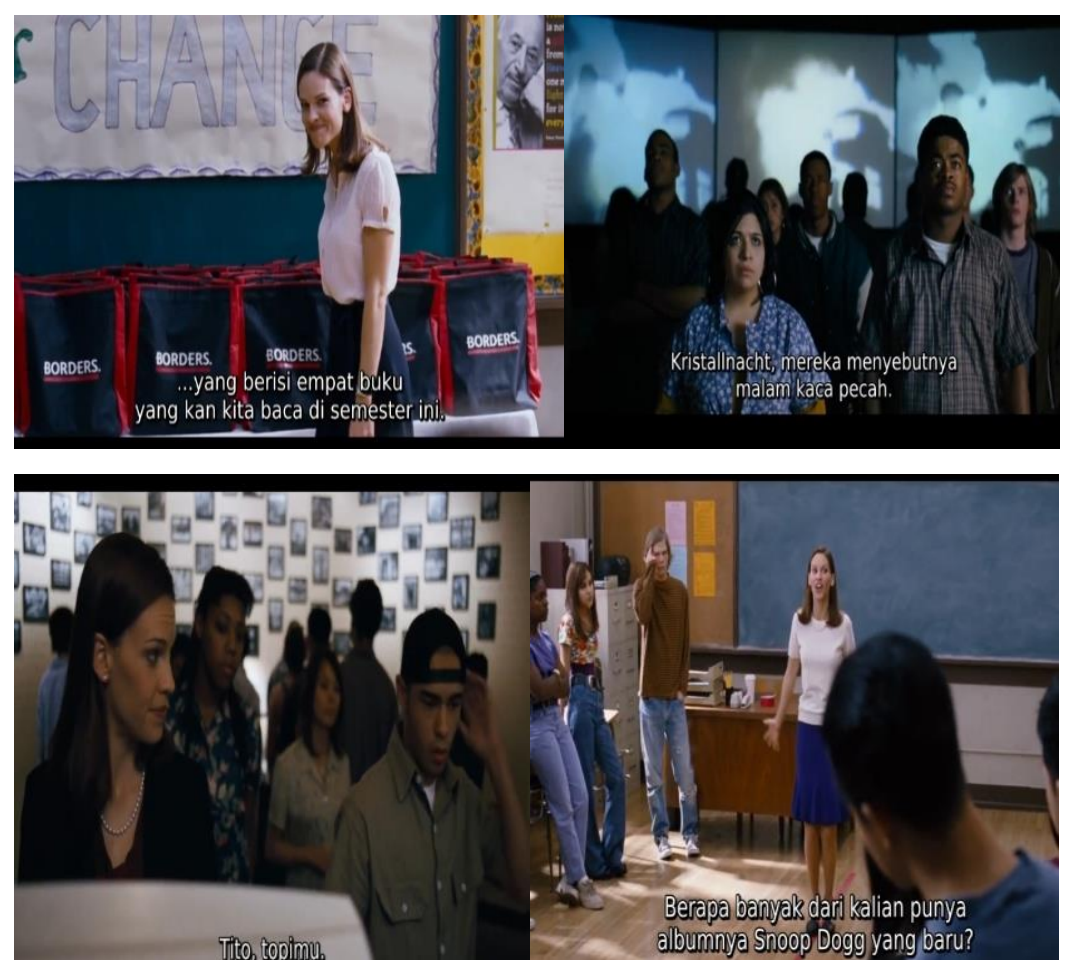

There are three components in this variation, visual, aural and tactile variation skills in the film. Mrs Gruwell applied all the components of skills. She gave her students printed material when she taught about poetry to hand and see the correct writing of the lyric.

One of these scenes shows that Mrs Gruwell gives the game to students, so the teaching and learning process that she carries on is not about lecturing and explaining the material, but she also gives variation by inviting the students to involve in the game.

In another meeting, Mrs Gruwell gives the book to her students. It is done because she wants to know the student's motivation to study. She asks the students to write their feelings about everything. She did not give limitation about the topics or themes that may be written. She wants her students to express their feeling because that will make them practice their writing. In another scene, Mrs Gruwell invited her students to go to the museum to see the real pictures and see the pieces of evidence of the Holocaust Tragedy.

3. Interaction Variation 
Picture. 4.6. Teacher and student's interaction
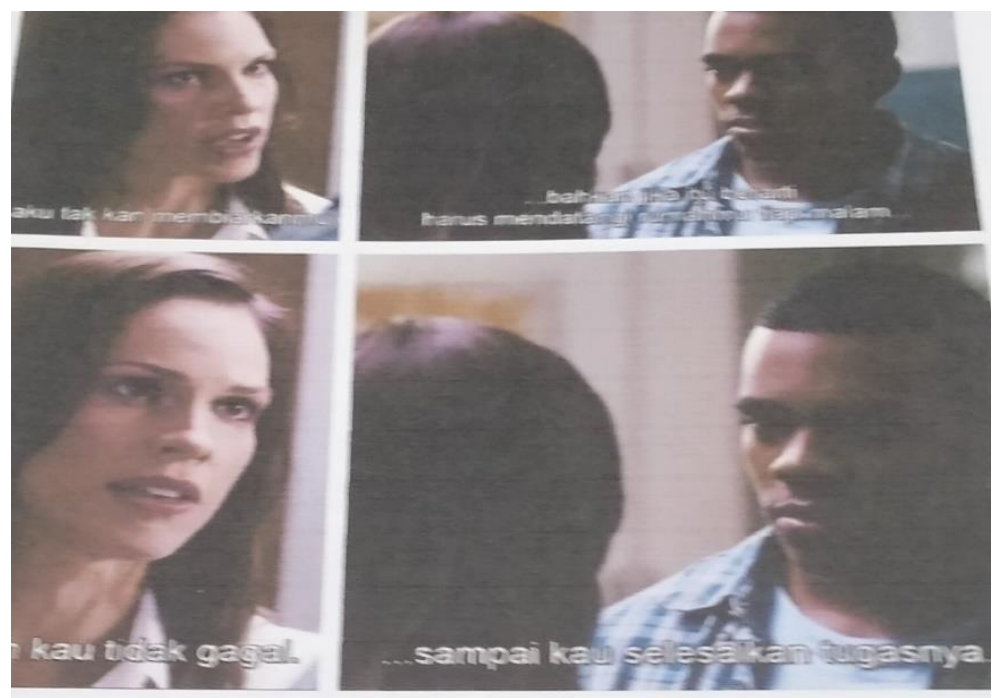

Interaction is becoming more important in the teaching and learning process. In this film, we can see from the scene that Mrs Gruwell interacted with the whole class by accepting feeling, praising or encouraging, accepting or using students' ideas, asking questions, lecturing and giving directions. The teacher also interacted with individual students by accepting feeling, reminding noisy students, and helping the student's work. It has happened when one of her student who gets a bad test result. Mrs Gruwell supports and asks him to re-examine because she knew that her students could do better.

\section{CONCLUSION}

Freedom Writers is a movie based on the real-life story of a teacher in California, Erin Gruwell, who is played by Hillary Swank. Based on the finding and discussions above, it can be concluding that the teacher or Mrs Gruwell in the film "Freedom Writers" applied the component of variation skill in the teaching and learning process in the class. She 
did six variations in the teacher's manner. She used various materials and media to make her lesson more interesting, and also, she always interacted with all students in her class. 


\section{REFERENCES}

Asril, Z. (2013). Micro Teaching disertai Dengan Pedoman Lapangan. Rajawali Pers.

Rusnawati. (2012). Component of Variation Skill in Teaching English Used by The Seventh Grade English Teacher of SMP N 1 Tamban. STKIP PGRI Banjarmasin.

Sani. (2012). Component of Variation Skill in Teaching English Used By Class E of English Departmentof STKIP PGRI Banjarmasin. STKIP PGRI Banjarmasin.

Turney, C. (1983). Reinforcement, basic questioning, variability (Sydney micro skills, redeveloped). International Scholarly Book Services. 